\title{
Seed quality, water use efficiency and eco physiological characteristics of Lallemantia (Lallemantia sp.) species as effected by soil moisture content
}

\author{
Mina ABDOLAHI ${ }^{1}$, Saeideh MALEKI FARAHANI ${ }^{1},{ }^{2}$
}

Seed quality, water use efficiency and eco physiological characteristics of Lallemantia (Lallemantia sp.) species as effected by soil moisture content

Abstract: This study investigated the effect of drought stress on the yield, water use efficiency (WUE), physiology, and seed quality of two species Lallemantia sp. Field experiments with three irrigation regimes were carried out in a split plot factorial in a randomized complete block design with three replications. Treatments included irrigation after $40 \%, 60 \%$, and $100 \%$ depletion of available soil water (ASW) $\left(\mathrm{I}_{40}, \mathrm{I}_{60}\right.$, and $\mathrm{I}_{100}$ respectively) as main plots and Lallemantia species $L$. iberica (M. Bieb.) Fisch. \& C. A. Mey. $\left(\mathrm{S}_{1}\right)$ and L. royleana Benth. in Wall $\left(\mathrm{S}_{2}\right)$ as subplots. Increment in depletion of ASW ( $\mathrm{I}_{40}$ to $\mathrm{I}_{100}$ ) resulted in progressively less chlorophyll a content (Chl a), open stomata percentage (OS), and leaf area index (LAI). The highest Chl a and LAI were found to be $0.0087 \mathrm{mg} \mathrm{g}^{-1}$, and $2.68 \mathrm{mg} \mathrm{g}^{-1}$ leaf mass in $\mathrm{I}_{40}$ treatment, respectively, while closed stomata percentage (CS) increased significantly as drought stress increased. The results of this experiment indicated that the appropriate yield of production was obtained in plots which were fully irrigated $\left(\mathrm{I}_{40}\right)$ for all species of Lallemantia; however, the WUE increased as drought stress increased. The interaction of drought stress, Lallemantia species with grain yield and WUE was significant.

Key words: Lallemantia; drought stress; leaf area; water productivity
Received July 15, 2018; accepted June 23, 2019.

Delo je prispelo 15. julija 2018, sprejeto 23. junija 2019.
Vpliv vsebnosti vode $\mathrm{v}$ tleh na kakovost semen, učinkovitost izrabe vode in ekofiziološke lastnosti različnih vrst lalemancije (Lallemantia sp.)

Izvleček: V raziskavi so bili preučevani učinki sušnega stresa na pridelek, učinkovitost izrabe vode (WUE), fiziologijo in kakovost semen dveh vrst lalemancije (Lallemantia sp.). Poljski poskus s tremi režimi namakanja je bil izveden kot popolni bločni faktorski poskus $\mathrm{z}$ deljenkami s tremi ponovitvami. Obravnavanja so obsegala namakanja po $40 \%$, $60 \%$, in $100 \%$ zmanjšanju razpoložljive vode $\mathrm{v}$ tleh $\left(\mathrm{ASW}, \mathrm{I}_{40}, \mathrm{I}_{60}\right.$, and $\left.\mathrm{I}_{100}\right)$, na glavnih ploskvah in vrste lalemancije, L. iberica (M. Bieb.) Fisch. \& C. A. Mey. $\left(\mathrm{S}_{1}\right)$ in L. royleana Benth. in Wall $\left(\mathrm{S}_{2}\right)$ na podploskvah. Povečanje pomanjkanja vode (iz $\mathrm{I}_{40}$ na $I_{100}$ ) je povzročilo progresivno zmanjšanje vsebnosti klorofila a, zmanjšanje odstotka odprtih listnih rež (OS), in zmanjšanje indeksa listne površine (LAI). Največji vrednosti vsebnosti klorofila a in indeksa listne površine sta bili izmerjeni, $0,0087 \mathrm{mg} \mathrm{g}^{-1}$, in $2,68 \mathrm{mg} \mathrm{g}^{-1}$ listne mase, pri obravnavanju $\mathrm{I}_{40}$ medtem, ko se je odstotek zaprtih rež (CS) z večanjem sušnega stresa značilno povečal. Rezultati raziskave kažejo, da je bil najboljši pridelek dosežen na dobro namakanih ploskvah $\left(\mathrm{I}_{40}\right)$ pri obeh vrstah lalemancije a učinkovitost izrabe vode se je s sušnim stresom povečevala. Medsebojni vpliv sušnega stresa, vrst lalemancije, pridelka zrnja in učinkovitosti izrabe vode je bil dokaj velik.

Ključne besede: Lallemantia; sušni stress; listna površina; učinkovitost izrabe vode

1 Shahed University, Department of Crop Production and Plant Breeding, Tehran,Iran

2 Corresponding author, e-mail: maleki@shahed.ac.ir 


\section{INTRODUCTION}

Lallemantia, commonly known as Balangu, belongs to the family of Labiatae and is represented by five species: L. iberica (M. Bieb.) Fisch. \& C. A. Mey, L.baldshuanica Gontsch., L. royleana Benth. in Wall, L canescens (L.) Fischer \& C.A.Mey., and L. peltata (L.) Fisch. \& C.A.Mey. (Rechinger, 1982). It is found in different regions of European and Middle East countries, especially Iran (Zargari 1980; Naghibi et al., 2005). Lallemantia is an annual or perennial herb, a dwarf shrub (Anonymans, 2003), and is characterized by simple, ovate to round or sometimes linear, aristae-toothed bracteole, oblong, trigonous, smooth, and mucilaginous nettled leaves (Harley et al. ,2004). It is a good source of fiber, oil, and protein and has medicinal properties (Naghibi et al., 2005). This natural herb is used for the treatment of reflux of stomach (Anonymans, 2012), arthritis, joint pain, rheumatism, osteoarthritis, and abscesses (Mahmood et al., 2013). Balangu seeds are used in a wide range of traditional and industrial products such as a beverage namely Tokhme Sharbati and a bread in Iran and Turkey (Mahmood et al., 2013). The seed contains up to $30 \%$ of a drying oil used for lighting, as a varnish, in paints as a lubricant (Usher, 1994), as a wood preservative, as an ingredient in oil-based paints, in furniture polishes, in printing inks, and in soaps. The oil could also be used for oil-foods and as a tanning agent. It is also used in the manufacture of linoleum (Anonymans, 2003). Sustainability and the overall management of water resources have been the greatest challenges of the century. World population has passed the six billion mark. Based on the proportion of young people in developing countries, the requirement for water will continue to increase significantly during the next few decades. This places an enormous demand on the world's limited irrigation water supply; thus, a precise knowledge of crop water requirements has become an essential prerequisite for the efficient use of water supplies (Reddy, 1999). Plants exposed to drought or drought stress have evolved a series of morphological and physiological adaptations which gives them tolerance to these stresses (Kumar et al., 2005). The degree of adaptation to the decrease in water potential caused by drought may vary considerably between species (Savé et al., 1995) and also within a species (Parker \& Pallardy, 1985). Drought stress decreases the rate of photosynthesis (Kawamitsu et al., 2000; Rivero et al., 2007). Plants grown under drought conditions have a lower stomatal conductance in order to conserve water. Consequently, $\mathrm{CO}_{2}$ fixation is reduced and photosynthetic rate decreases, resulting in less assimilate production for plant growth and yield. Diffusive resistance of the stomata to $\mathrm{CO}_{2}$ entry is probably the main factor limiting photosynthesis in drought (Boyer, 1970). Certainly, under mild or moderate drought stress, stomatal closure causing reduced internal leaf $\mathrm{CO}_{2}$ concentration is the major reason for reduced rates of leaf photosynthesis (Chaves, 1991; Cornic, 2000; Flexas et al., 2004; Romero-Romero et al., 2018). Another plant response to drought stress is to change the content of photosynthetic pigments that play important roles in light harvesting (Farooq et al., 2009; Ommen et al., 1999). Severe drought stress also inhibits plant photosynthesis by causing changes in chlorophyll content, by affecting chlorophylls components, and by damaging the photosynthetic apparatus (Iturbe-Ormaetxe et al., 1998). Drought stress causes a large decline in the chlorophyll $a$ content, the chlorophyll $b$ content, and the total chlorophyll (Manivannan et al., 2007). The decrease in chlorophyll under drought stress is mainly the result of damage to chloroplasts caused by reactive oxygen species (Ramireza et al., 2014). The effects of drought stress on chlorophyll and carotenoids content have been investigated some crops including cotton (Mssacci et al., 2008) and Catharanthus roseus (L.) G.Don (Jaleel et al., 2008). Water deficit reduces leaf area and the number of leaves per plant and leads to a reduction in crop growth. Loss of leaf area, which could result from the reduced size of younger leaves and the inhibition of the expansion of developing foliage, is also considered an adaptation mechanism to drought (Gebeyehu, 2006). In bean, reduced leaf area causes a decrease in canopy temperatures and a cooling of the plant growth environment (Ghanbari et al., 2013). Wentworth et al. (2006) determined the photosynthetic characteristics of two contrasting varieties of the common bean (Phaseolus vulgaris L.) under drought stress. Both varieties showed reduced chlorophyll content on a leaf area basis, a decrease in leaf area, and an increase in leaf thickness. Numerous biochemical changes occur in response to drought stress. Changes in mucilage ( $\mathrm{Ra}-$ himi et al., 2011) and protein accumulation and synthesis have been observed in many plants species as a result of plant exposure to drought stress during growth (Chen \& Tabaeizadeh, 1992; Salehi et al., 2016; Omidi et al., 2018). The study of water use efficiency becomes particularly important in situations where growth is affected by limited water availability (Anyia \& Herzog, 2004). Maximum water use efficiency is achieved at the limit between diffusional and metabolic limitations to photosynthesis (Flexas et al., 2004). However, there is still a lack of information about the morpho-physiological behavior of different Lallemantia species under conditions of limited water availability. Therefore, the main objective of this study was to determine the response of different species of Lallemantia to drought stress by evaluating their productivity and selected morphological, physiological, and biochemical parameters. 


\section{MATERIALS AND METHODS}

\subsection{CROP PRODUCTION, TREATMENTS AND EXPERIMENTAL DESIGN}

The field experiment was conducted at the Research Farm of the Agricultural College of Shahed University, Tehran (Fig 1), during the years 2012-2014. Prior to preparing the plots, five points were sampled at a depth of $30 \mathrm{~cm}$, and soil analyses were conducted. The soil type was loam-silty, the percentage of organic carbon was 0.77 , the $\mathrm{N}$ content was $0.08 \%$, the exchangeable $\mathrm{K}$ and available $\mathrm{P}$ content were $382 \mathrm{mg} \mathrm{kg}^{-1}$ and $22.3 \mathrm{mg} \mathrm{kg}{ }^{-1}$, respectively, and the $\mathrm{pH}$ was about 8 . The climate was arid to semiarid with an average rainfall of $216 \mathrm{~mm}$ per year. Some physical properties of the soil layer at a depth of $30 \mathrm{~cm}$ are given in Table 1.

In this study, the Lallemantia species were used as the crop material. After field preparations, the experimental area was divided into 36 plots measuring $3 \times$ $1.5 \mathrm{~m}$ in size. Between contiguous plots a distance of 1 $\mathrm{m}$ in each replication and $1.5 \mathrm{~m}$ between replications was maintained. The seeds were sown on the $14^{\text {th }}$ of March 2012 at a row spacing of $25 \mathrm{~cm}$ and plant spacing of $5 \mathrm{~cm}$ in the rows. Cultivation practices, such as weeding, thinning, fertilizing, etc., were applied according to crop needs. The field experiment was designed as a split plot factorial in a complete randomized block design with three replications. The main factor was irrigation treatments, scheduled based on depletion of ASW over $30 \mathrm{~cm}$ soil depth including $40 \%, 60 \%$, and $100 \%$ depletion of ASW (abbreviated to $\mathrm{I}_{40}, \mathrm{I}_{60}$, and $\left.\mathrm{I}_{100}\right)$. The second factor was two species of Lallemantia L. royleana $\left(\mathrm{S}_{1}\right)$, L. iberica $\left(\mathrm{S}_{2}\right)$. All plots received the same amount of water from germination to flowering. The irrigation treatments were applied at the onset of flowering. The percentage depletion of water (ASW) in the $0-30 \mathrm{~cm}$ layer of soil was estimated by measuring the soil water content gravimetrically using Eq. (1) (Martin et al., 1990):

$$
\text { Eq. (1) } \quad D(\%)=100 \times \frac{F c-\theta}{F c-W p}
$$

Where $D$ is depletion, $F_{C}$ is the soil moisture at field capacity, $\theta$ is the soil moisture, and $W p$ is the soil moisture at wilting point. The amount of water applied based on each treatment was calculated using Eq. (2) (Rostamza et al., 2011):

$$
\text { Eq. (2) } \quad I_{n}=\frac{(F C-\theta) \times D \times A}{100}
$$

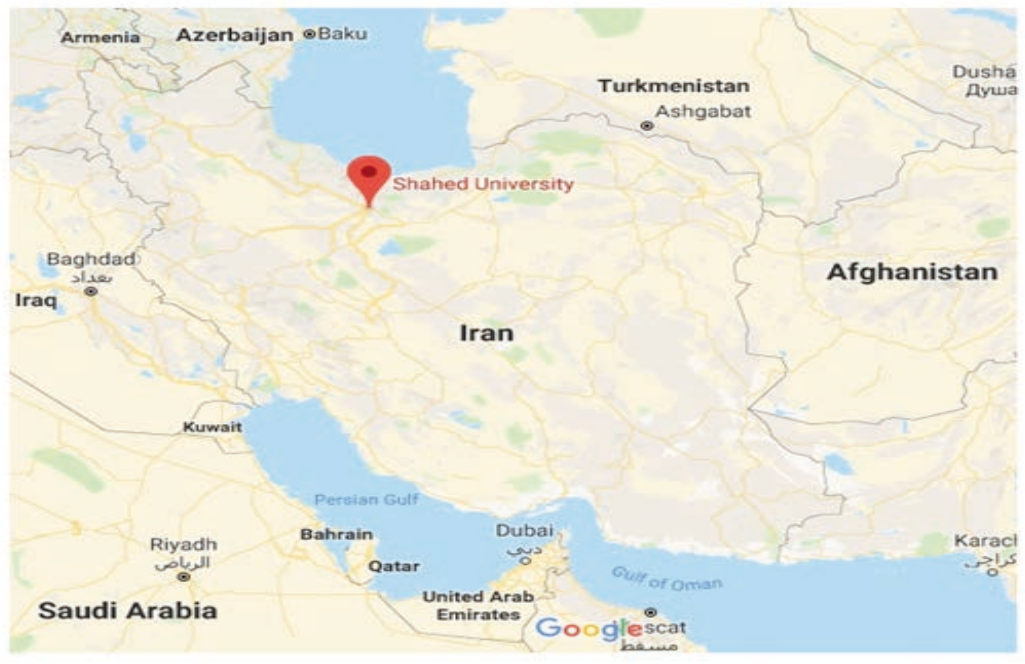

Figure 1: Geographical location of experiment

\begin{tabular}{|c|c|c|c|c|c|c|}
\hline \multicolumn{4}{|c|}{ Particle size distribution (\%) } & \multirow{2}{*}{$\begin{array}{l}\text { Bulk density } \\
\left(\mathrm{g} \mathrm{cm}^{-3}\right)\end{array}$} & \multirow{2}{*}{$\begin{array}{l}\text { Field capacity } \\
\text { (\% gravimetrica }\end{array}$} & \multirow{2}{*}{$\begin{array}{l}\text { Wilting point } \\
\text { (\% gravimetrically) }\end{array}$} \\
\hline Clay & Silt & Sand & Soil type & & & \\
\hline 18 & 24 & 58 & Loam-silty & 1.8 & 21.2 & 11 \\
\hline
\end{tabular}

Table 1: Some physical properties of 0-30 cm layer of soil 
Where $I_{n}$ is the volume of irrigation water, $D$ is the effective rooting depth, and $\mathrm{A}$ is the plot surface area. The surface area of each plot measured $4.5 \mathrm{~m}^{2}$. Each plot was watered individually through the furrows. Before applying irrigation treatments, the amount of water required was determined by monitoring changes in soil water gravimetrically. Every 2 days a soil sample was taken from a depth of $0-30 \mathrm{~cm}$, dried in an oven at $105^{\circ} \mathrm{C}$ for $24 \mathrm{~h}$, and then the soil moisture was measured.

\subsection{SAMPLING AND ANALYZING}

\subsubsection{Water use efficiency (WUE)}

WUE is a quantitative measurement of how much biomass or yield is produced over a growing season, normalized with the amount of water used up in the process (Anonymous, 1998). Besides absolute yield, water use efficiency is an important agronomic factor, especially in agricultural irrigation systems and in climate areas where a limited amount of water from the rainy season has to last for the whole growth period as no further rainfall can be expected (Anonymous, 1998). In this experiment the WUE was calculated as the economical yield per unit of evapotranspiration of the crop.

$\left(\mathrm{WUE}=\mathrm{Y} \mathrm{ET}^{-1}\right)$. ET was calculated using Eq. (4) (Garrity et al., 1982):

\section{Eq. (4)}

$$
\mathrm{ET}-\mathrm{P}+\mathrm{I}-\mathrm{R}-\mathrm{D}_{\mathrm{v}} \pm \Delta \mathrm{S}
$$

Where ET is crop water consumption $(\mathrm{mm}), P$ is rainfall $(\mathrm{mm}), I$ is irrigation water $(\mathrm{mm}), R$ is surface runoff $(\mathrm{mm}), D_{p}$ is deep percolation $(\mathrm{mm})$, and $\Delta S$ is soil water content variation in crop root depth $(\mathrm{mm})$. Therefore, total ET values were calculated using a summation of all ET during the growing season. In this study, $D_{\mathrm{p}}$ and $R_{\mathrm{f}}$ in Eq. (4) were assumed to be negligible. Since the slope of each plot was near zero and the amount of irrigation water was only enough to reach field capacity, it was also assumed that there was no deep percolation.

\subsubsection{Chlorophyll content}

Chlorophyll content was measured in each irrigation treatment, $\mathrm{I}_{40}, \mathrm{I}_{60}$, and $\mathrm{I}_{100}$, and for every Lallemantia species. Measurements were performed on the appropriate method of Arnon (1994) with a modified formula (Porra, 2002). Chl was extracted by grinding $0.1 \mathrm{~g}$ of leaf material in $80 \%$ acetone. The extract was centrifuged at
$3000 \mathrm{rpm}$ for $5 \mathrm{~min}$, the supernatant was collected, and the process was repeated until the pellet became white or yellow in color. The supernatants were pooled, and absorption was read by spectrophotometer (Model Spectronic 20; Milton Roy Co., USA) at wavelengths of 645 $\mathrm{nm}, 663.6 \mathrm{~nm}$, and $664.4 \mathrm{~nm}$. Eventually the optical density was noted for the estimated chlorophyll content (Saraswathi \& Paliwal, 2011) using Eq. (4).

$$
\begin{aligned}
& \text { Eq. (4): } \\
& \text { Chlorophyll a }\left(\mu \mathrm{g} \mathrm{ml}^{-1}\right)=12.25\left(\mathrm{~A}_{663.6}\right)-2.55\left(\mathrm{~A}_{646.6}\right) \\
& \text { Chlorophyll b }\left(\mu \mathrm{g} \mathrm{ml}^{-1}\right)=20.31\left(\mathrm{~A}_{646}\right)-4.91\left(\mathrm{~A}_{663.6}\right) \\
& \text { Total chl }\left(\mu \mathrm{g} \mathrm{ml}^{-1}\right)=17.76\left(\mathrm{~A}_{646.6}\right)+7.34\left(\mathrm{~A}_{663.6}\right)
\end{aligned}
$$

\subsubsection{Leaf area index (LAI)}

Leaf area index is defined as the one sided leaf area of a plant per the ground area covered by canopy (Burton et al., 1991; Cutini et al., 1998). The area of each leaf was measured per $2.0 \mathrm{~m}^{2}$ of every plot with a leaf area meter (AM200, Bioscientific Co.). To calculate the leaf area, the number of leaves was multiplied by the average leaf area.

\subsubsection{Leaf stomata variation}

Optical microscopy was used to assess the response of Lallemantia species leaf stomata to irrigation regimes. A very thin layer of the abaxial epidermis was taken. After the chlorophyll was removed with bleach and distilled water, lam and lamella samples were prepared (Akbarinia et al., 2012). Then the percentage of closed and open leaf stomata was calculated per $1.0 \mathrm{~mm}^{2}$.

\subsubsection{Root length variation}

In June 2012, at the end of the experiment, plant roots were extracted, the attached soil was removed by washing, and the root length was determined using the line intersection method (Tennant, 1975) from which root length could be calculated for soil layer samples from a depth of $30 \mathrm{~cm}$.

\subsubsection{Yield production}

In this experiment, plants were harvested 3 months after planting, right after the physiological maturity of Lallemantia to avoid losing plant material. The effects of 
the drought treatments on seed yield were assessed. Samples were collected from $2.0 \mathrm{~m}^{2}$ of plot.

\subsubsection{Seed quality}

Seed chemical composition was determined as protein percentage by determining the nitrogen content using the Micro kjeldahl method (Cohen, 1910). The nitrogen percentage was multiplied by 6.25 to calculate the percentage of protein in the seeds. Seed mucilage was measured for every treatment using Kalnyasundaram's method (1982). Measures of protein yield and mucilage yield were obtained by multiplying the percentage of protein and mucilage by seed yield.

\subsubsection{Data analysis}

Statistical software was used for data analysis, correlations, and all mean comparisons (Duncan). A p-value of 0.01 was considered statistically significant. All graphs were drawn using Microsoft Office Excel

\section{RESULTS}

\subsection{WEATHER CONDITIONS AND IRRIGATION}

The average monthly maximum air temperature varied between $11^{\circ} \mathrm{C}$ and $38.7^{\circ} \mathrm{C}$, and the average temperature exceeded $35{ }^{\circ} \mathrm{C}$ in June. The lowest average monthly minimum temperature of $2.2^{\circ} \mathrm{C}$ was observed in February (Fig. 2). The number of irrigation treatments and total water volume applied during the experiment are shown in Table 2 . The interaction between irrigation treatments and species were observed on the LAI of the Lallemantia species (Fig 3).

\subsection{THE EFFECT OF WATER STRESS ON GROWTH COMPONENTS OF LALLEMANTIA SPECIES}

\subsubsection{Leaf area index (LAI)}

The variance analysis indicated that LAI of the Lallemantia species was significantly affected $(P<0.01)$ by the interaction effect of irrigation regimes and species (Table 3). LAI was directly affected by the amount of water applied. The highest values were seen in $\mathrm{I}_{40}$, and they decreased as drought stress increased (Fig. 2). Under severe drought stress conditions $\left(\mathrm{I}_{100}\right)$, the LAI was the least in both species. There was no significant difference in the LAI of $L$. royleana in any irrigation system, however in L. iberica the LAI was significantly reduced as drought stress increased. As the water depletion increased in $\mathrm{I}_{60}$ and $\mathrm{I}_{100}$, the LAI decreased $24.6 \%$ and $49.62 \%$, respectively compared to $\mathrm{I}_{40}$ in L. iberica (Fig. 3). The mean comparison of LAI in Fig. 2 showed that in all species, the leaf area index decreased during plant growth as the intensity of drought stress increased. As the water depletion increased in $\mathrm{I}_{60}$ and $\mathrm{I}_{100}$, leaf area index decreased. Among drought adaptation strategies, the minimization

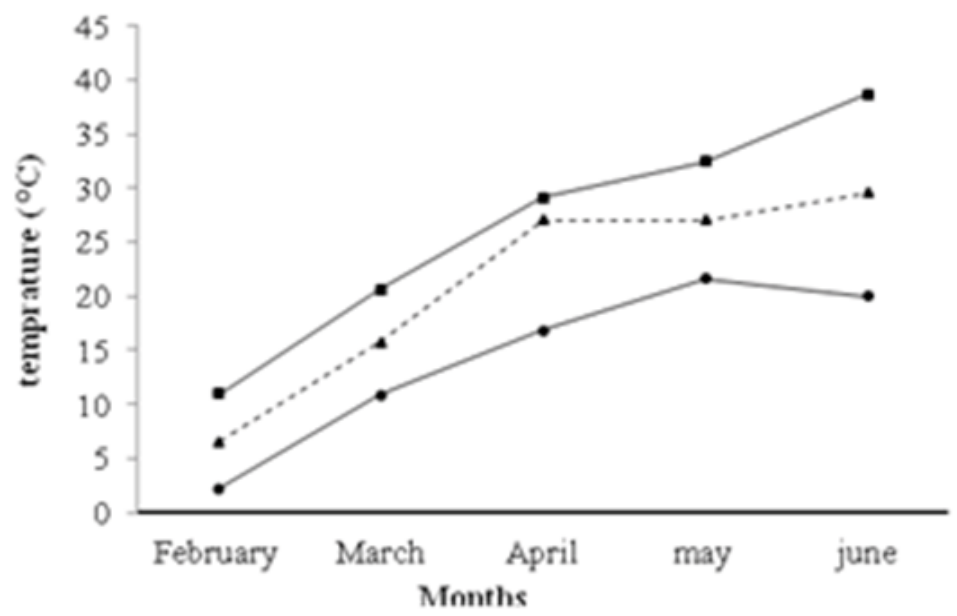

Figure 2: Average monthly maximum (--), minimum (-•-) and mean $(-\Delta-)$ temperatures $\left({ }^{\circ} \mathrm{C}\right)$ for the experimental site in 2012-2014. 
Table 2: Number of irrigations and amount of water applied per irrigation treatments to Lallemantia species plots after starting water regimes

\begin{tabular}{lll}
\hline Treatments & Number of irrigation & Total amount of applied water (mm) \\
\hline I40 S1 & 9 & 237 \\
I40 S2 & 9 & 238 \\
Mean & & 235.75 \\
& 5 & 200 \\
I60 S1 & 5 & 199 \\
I60 S2 & & 199.25 \\
Mean & & \\
I100 S1 & 2 & 117 \\
I100 S2 & 2 & 115 \\
Mean & & 113.5 \\
\hline
\end{tabular}

Table 3: Analysis of variance of chlorophyll a ( $\mathrm{Chl} \mathrm{a),} \mathrm{chlorophyll} \mathrm{b} \mathrm{(Chl} \mathrm{b),} \mathrm{total} \mathrm{chlorophyll} \mathrm{(Ch} \mathrm{T),} \mathrm{percentage} \mathrm{of} \mathrm{closed} \mathrm{stomata}$ (CS), percentage open stomata (OS), leaf area index (LAI), root length (RL), water use efficiency (WUE), yield (Y) and thousand seed mass (TSM)

\begin{tabular}{|c|c|c|c|c|c|c|c|c|c|c|c|}
\hline S.O.V & df & Mean square & & & & & & & & & \\
\hline & & $\mathrm{Chl} \mathrm{a}$ & $\mathrm{Chl} \mathrm{b}$ & $\mathrm{Chl} \mathrm{T}$ & $\% \mathrm{CS}$ & $\% \mathrm{OS}$ & LAI & $\mathrm{RL}$ & WUE & $\mathrm{Y}$ & TSD \\
\hline Block & 2 & $2.5 \times 10^{-7}$ n..5. & $7.77 \times 10^{-7} \mathrm{n}$. $\mathrm{m}$. & $9.11 \times 10^{-7}$ n..5. & 41.49 n.s. & $41.45^{\mathrm{n} .5 \mathrm{~s}}$ & $0.105^{\text {n.s. }}$ & $0.118^{n .5 .}$ & $0.234^{\text {n.s. }}$ & $1481.6^{\text {n.s. }}$ & $7 \times 10^{-5}$ n.s. \\
\hline Irrigation & 2 & $3.7 \times 10^{-6 * 8}$ & $2.40 \times 10^{-6}$ n.s. & $1.82 \times 10^{-6} 6 \mathrm{n} . \mathrm{s}$ & $7936.59^{* *}$ & $7936.92^{* *}$ & $5.260^{* *}$ & $0.806^{\text {n.s. }}$ & $0.583^{*}$ & $29815.5^{*}$ & $312 \times 10^{-5^{* *}}$ \\
\hline Lallemantia species & 1 & $2.2 \times 10^{-6 * 8}$ & $1.84 \times 10^{-6}$ & $7.93 \times 10^{-6}$ & 210.73 n.s. & 210.64 n.s. & $6.890^{* 8}$ & $0.0001^{\text {n.s. }}$ & $0.260^{\text {n.s. }}$ & $909.03^{\text {n.5. }}$ & $45 \times 10^{-6}$ n.s. \\
\hline Irrigation $\times$ species & 2 & $6.25 \times 10^{-7} \mathrm{n.s}$. & $5.54 \times 10^{-7} \mathrm{~nm} . \mathrm{m}$ & $4.34 \times 10^{-7} \mathrm{~ns}$. & 344.13 n.s. & 344.08 n.s. & $2.041^{* *}$ & $0.282^{\text {n.s. }}$ & $0.389^{*}$ & $6642.9^{\text {n.s. }}$ & $17 \times 10^{-4} \mathrm{n.s}$ \\
\hline Error & 18 & $1.8 \times 10^{-7}$ & $1.42 \times 10^{-6}$ & $1.43 \times 10^{-6}$ & 116.95 & 116.97 & 0.150 & $1.186^{\text {n.s. }}$ & 0.176 & 2131.69 & $14 \times 10^{-6} \mathrm{~nm}$ \\
\hline Total & 35 & & & & & & & & & & \\
\hline
\end{tabular}

*,**: significant at $5 \%$ and $1 \%$ probability levels, respectively, and n.s: non-significant.

of water loss can be achieved through lowering either leaf area or stomatal conductance or by reducing the energy load of the plant (Rauf \& Sadaqat, 2008). It is noteworthy that yield was not significantly different between $S_{1}$ and $\mathrm{S}_{2}$, but as drought intensity increased, LAI decreased in $\mathrm{S}_{1}$ significantly. Therefore, it is concluded that $\mathrm{S}_{1}$ is more sensitive to soil water depletion than $S_{2}$. Pandy et al. (2000) found that reducing LAI to decrease transpiration and deepening the root system to increase water extraction are adaptive strategies in maize plants under water stress. Hence, dry matter production decreases with a decrease in the leaf area index. Similar results were also

Table 4: Analysis variance of seed quality of Lallemantia species under irrigation treatments

\begin{tabular}{|c|c|c|c|c|c|}
\hline \multirow[t]{2}{*}{ S.O.V } & \multirow[t]{2}{*}{$\mathrm{df}$} & \multicolumn{4}{|c|}{ Mean square } \\
\hline & & Protein \% & Protein yield & Mucilage \% & Mucilage yield \\
\hline Block & 2 & $1.30^{\mathrm{n} . \mathrm{s}}$ & $2.40^{\mathrm{n} . \mathrm{s}}$ & $0.068^{\mathrm{n} . \mathrm{s}}$ & $5.65^{\mathrm{n} . \mathrm{s}}$ \\
\hline Irrigation & 2 & $2.24^{\text {n.s }}$ & $39.29^{*}$ & $8.08^{* *}$ & $60.01^{*}$ \\
\hline Lallemantia species & 1 & $61.09^{* *}$ & $30.28^{* *}$ & $54.02^{* *}$ & $16.78^{\mathrm{n} . \mathrm{s}}$ \\
\hline Irrigation species & 2 & $8.87^{*}$ & $8.90^{\mathrm{n} . \mathrm{s}}$ & $0.772^{\text {n.s }}$ & $20.32^{\text {n.s }}$ \\
\hline Error & 18 & 1.55 & 2.70 & 1.217 & 9.82 \\
\hline Total & 35 & & & & \\
\hline
\end{tabular}

**** significant at $5 \%$ and $1 \%$ probability levels, respectively, and n.s: non-significant 


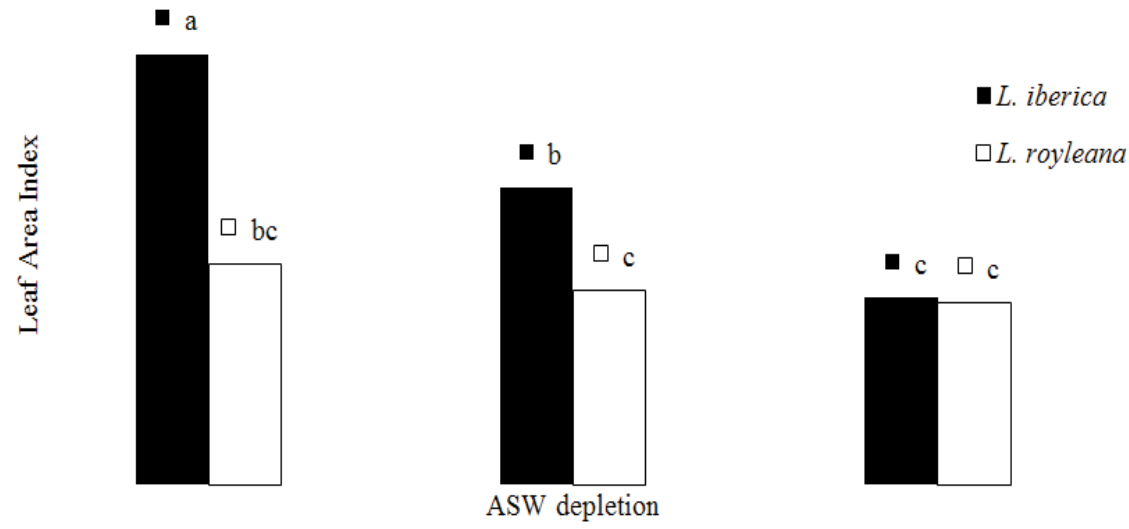

Figure 3: The interaction of water stress and Lallemantia sp on leaf area index (LAI). Different letters indicate significant difference ( $\mathrm{p}$ 0.01) according to Duncan test.

reported by Tashiro and Wardlaw (1990). Stagnari et al. (2018) reported that the leaf area of radish reduced when the plants were exposed to drought stress. Rostamza et al. (2011) demonstrated a positive relationship between drought intensity and the reduction in LAI and dry matter from $7 \%$ to $45.5 \%$. This can be associated with the fact that plants exposed to water stress served the photosynthetic sources to stay green and produce more dry matter. Furthermore, Hopkins et al. (2008) stated that leaf size could increase with increasing air temperatures. Large leaves have thicker boundary layers of air around their surfaces which insulate them and decrease water loss through transpiration.

\subsubsection{Root Length}

Results given in Table 3 showed no significant effect in root length among all irrigation regimes and Lallemantia species. Drought stress decreased root length, but not significantly. The same result was reported in strawberry cultivars by Klamkowski and Tender (2008) who demonstrated that cultivars 'Elsanta' and 'Salut' were not affected by irrigation regimes. Generally, growth inhibition in response to reduced water availability was higher in the above-ground portions of the plants than in the root systems. A deeper, more extensive root system enables plants to increase water uptake and survive during drought stress (Klamkowski \& Tender, 2008).

Data of Chlorophyll a, Chlorophyll b, Total Chlorophyll, open and closed stomata, leaf area index, root length, water use efficiency, grain yield and grain qual-

Table 5: The mean chlorophyll a (Chl a), chlorophyll b ( Chl b), total Chlorophyll (Chl T), closed stomata (CS) open stomata percentage (OS) per $\mathrm{mm}^{2}$, leaf area index (LAI), root length (RL) water use efficiency (WUE), yield (Y), thousand seed weight, percentage of grain protein, grain protein yield, percentage of grain mucilage and grain mucilage yield of Lallemantia species affected by different irrigation regimes

\begin{tabular}{|c|c|c|c|c|c|c|c|c|c|c|c|}
\hline & 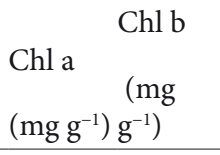 & $\begin{array}{l}\text { Chl T } \\
(\mathrm{mg} \\
\left.\mathrm{g}^{-1}\right)\end{array}$ & OS & LAI & $\begin{array}{l}\mathrm{RL} \\
(\mathrm{cm})\end{array}$ & $\begin{array}{l}\text { WUE } \\
\left(\mathrm{kg} \mathrm{m}^{-3}\right)\end{array}$ & $\begin{array}{l}\text { Y TSW } \\
\left(\mathrm{kg} \mathrm{ha}^{-1}\right)\end{array}$ & protein & $\begin{array}{l}\text { Protein } \\
\text { yield }\end{array}$ & $\begin{array}{l}\text { Muci- } \\
\text { lage }\end{array}$ & $\begin{array}{l}\text { Mu- } \\
\text { cilage } \\
\text { yield }\end{array}$ \\
\hline \multicolumn{12}{|c|}{ Irrigation level } \\
\hline $\mathrm{I} 40$ & 0.0087 a 0.0098 a & a 0.0175 a $24.11 b$ & $75.88 \mathrm{a}$ & $2.68 \mathrm{a}$ & $6.02 \mathrm{a}$ & $1.18 \mathrm{ab}$ & 208.37 a 0.888 a & $21.57 \mathrm{a}$ & $7.27 \mathrm{a}$ & $5.46 \mathrm{c}$ & $11.22 \mathrm{a}$ \\
\hline $\mathrm{I} 60$ & 0.0082 a 0.0117 a & a 0.0199 a 64.61 a & $35.38 \mathrm{~b}$ & $2.02 \mathrm{ab}$ & $5.50 \mathrm{a}$ & $0.79 \mathrm{~b}$ & $127.01 \mathrm{~b} 0.866 \mathrm{~b}$ & $20.75 \mathrm{~b}$ & $3.96 \mathrm{~b}$ & $6.30 \mathrm{~b}$ & $6.75 \mathrm{~b}$ \\
\hline $\mathrm{I} 100$ & $0.0070 \mathrm{~b} 0.0107 \mathrm{a}$ & a 0.0180 a 71.82 a & $28.17 \mathrm{~b}$ & $1.35 \mathrm{~b}$ & $5.77 \mathrm{a}$ & $1.51 \mathrm{a}$ & $138.12 \mathrm{~b} 0.856 \mathrm{c}$ & $20.92 \mathrm{ab}$ & $4.34 \mathrm{~b}$ & $7.10 \mathrm{a}$ & $8.95 \mathrm{ab}$ \\
\hline \multicolumn{12}{|c|}{ Lallemantia species } \\
\hline S1 & $0.0079 \mathrm{~b} 0.011 \mathrm{a}$ & 0.0190 a 55.93 a & $44.89 \mathrm{a}$ & $2.45 \mathrm{a}$ & $5.76 \mathrm{a}$ & $1.24 \mathrm{a}$ & 167.06 a 0.95 a & $22.38 \mathrm{a}$ & $6.11 \mathrm{a}$ & $5.06 \mathrm{~b}$ & $8.29 \mathrm{a}$ \\
\hline S2. & 0.0084 a 0.009 a & 0.0180 a 51.10 a & $48.99 \mathrm{~b}$ & $1.58 \mathrm{~b}$ & $5.76 \mathrm{a}$ & $1.07 \mathrm{a}$ & $135.28 \mathrm{a} 0.78 \mathrm{~b}$ & $19.78 \mathrm{~b}$ & $4.27 \mathrm{~b}$ & $7.51 \mathrm{a}$ & $9.66 \mathrm{a}$ \\
\hline
\end{tabular}


ity characteristics were averaged for both Lallemantia species (L. iberica) $\mathrm{S}_{1}$, (L. royleana) $\mathrm{S}_{2}$. Values within the column followed by the different letters are significantly different according to the Duncan test at 0.01 probability level.

\subsubsection{Chlorophyll content}

Results showed that the effects of irrigation and species were not significant on chlorophyll $a$ content (Table 3). Drought stress also inhibited the photosynthesis of plants by affecting chlorophyll content and damage to the photosynthetic apparatus (Mafakheri et al., 2010). In this study, increasing the intensity of drought stress resulted in decreased chlorophyll a content. $S_{1}$ (L. iberica) showed the significant, lower chlorophyll $a$ content across all water stress treatments. The results of this study are in agreement with those of Nyachiro et al. (2001), who described a significant decrease in chlorophyll $a$ caused by water deficit in six Triticum aestivum L. cultivars. The effect of species on chlorophyll $b$ and total chlorophyll were not significant. Decreased or unchanged chlorophyll levels during drought stress and dependent upon the duration and severity of drought had been reported in other species (Kpyoarissis et al., 1995). The content of total chlo-

Figure 4: Linear regression between percentage of soil water depletion and percentage of open stomata in the fully expanded topmost leaf of the main shoot. The regression coefficient is significant at $p<0.01$.

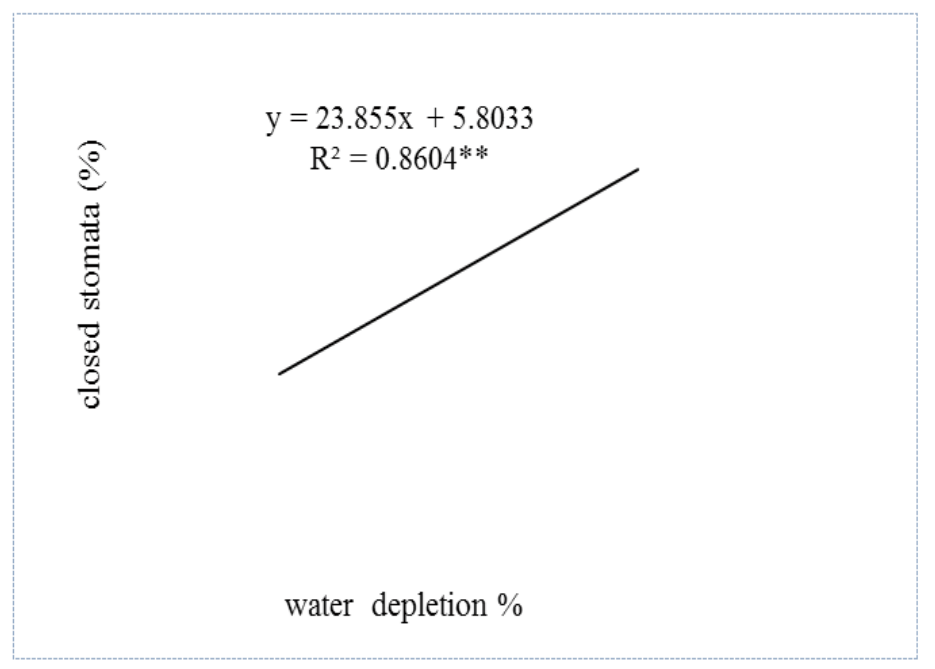

Figure 5: Linear regression between percentage of soil water depletion and percentage of closure stomata in the fully expanded topmost leaf of the main shoot. The regression coefficient is significant at $p<0.01$. 
rophyll on leaf dry mass increased with an increase in the intensity of drought stress, but not significantly. An increase of total chlorophyll under drought stress implies an enhanced capacity for light harvesting. Since the production of a reactive oxygen species is mainly driven by excess energy absorption in the photosynthetic apparatus, this might be avoided by degrading the absorbing pigments (Herbinger et al., 2002).

\subsubsection{Stomata responses to drought stress}

Variance analysis revealed that irrigation regimes had significant effects on the percentage of closed and open stomata $(p<0.01)$ (Table 3$)$. There was a linear regression $\left(\mathrm{R}^{2}=0.86^{* *}\right)$ between the percentage of soil water depletion and the percentage of closed and open stomata. (As drought stress increased, closed stomata increased, reaching the highest value in $\mathrm{I}_{100}$ (Fig 5). Open stomata showed a $75.8 \%$ reduction in $\mathrm{I}_{100}$ compared to the well irrigation treatment $\left(\mathrm{I}_{40}\right)$ (Fig 2). Water availability is a limiting factor for a wide range of physiological processes in plants. One of the first responses of plants to drought is stomatal closure, which restricts gas exchange between the inside of the leaf and the atmosphere. Therefore, this is the main means of regulating water relations and carbon assimilation in plants (Hetherington \& Woodward, 2003). Stomatal closure protects plants against excessive water loss, but also restricts the diffusion of $\mathrm{CO}_{2}$ into the photosynthetic parenchyma (Chaves et al., 2003). $S_{2}$ not only had more open stomata but also showed less closed stomata than $S_{1}$, indicating a high ability of $S_{2}$ to retain water in its tissues.

\subsection{WATER USE EFFICIENCY OF LALLEMANTIA SPECIES}

Water use efficiency is defined as the amount of dry matter production (grain) per unit of water consumed (evapotranspiration).The number of irrigation treatments and the total water volume applied during the experiment are shown in Table 2. The effect of irrigation regimes was significant $(p<0.05)$ on WUE (Table 3). The highest WUE was observed in $I_{100}$ and the lowest was reported for $\mathrm{I}_{60}$ (Table 5). WUE decreased $33.05 \%$ as drought stress intensity increased up to $60 \%$ ASW. As water depletion increased to more than $60 \%$, WUE increased $21.85 \%$ compared with $\mathrm{I}_{40}$, which was not significant (Table 5). The interaction between drought stress, Lallemantia species was significant (Table 3 ). The highest WUE by $1.96 \mathrm{~kg} \mathrm{~m}^{-3}$ was obtained in $\mathrm{I}_{100}$, L. royleana; the lowest WUE by $0.429 \mathrm{~kg} \mathrm{~m}^{-3}$ was reported for $\mathrm{I}_{60}, L$. royleana (Fig 6). In the present study, WUE varied significantly depending on water availability. The results shown in Table 5 revealed that the highest water use efficiency was obtained when irrigation was scheduled on minimum irrigation $\left(\mathrm{I}_{100}\right)$, while more soil water depletion of $\left(\mathrm{I}_{60}\right.$ and $\left.\mathrm{I}_{100}\right)$ improved WUE. The interaction between irrigation regimes showed that the behavior of Lallmantia species toward irrigation regimes was the same. The interaction of drought stress and Lallemantia species was significant. Our results are contrary to those reported in strawberry cultivars by Klamkowski and Tender (2008), who demonstrated that in drought stress, water use efficiency of the 'Salut' cultivar decreased. Our results were in agreement with the findings of Rostamza et al. (2011), Zegada-Lizarazu and Ijima (2005), and Nagaz et al.

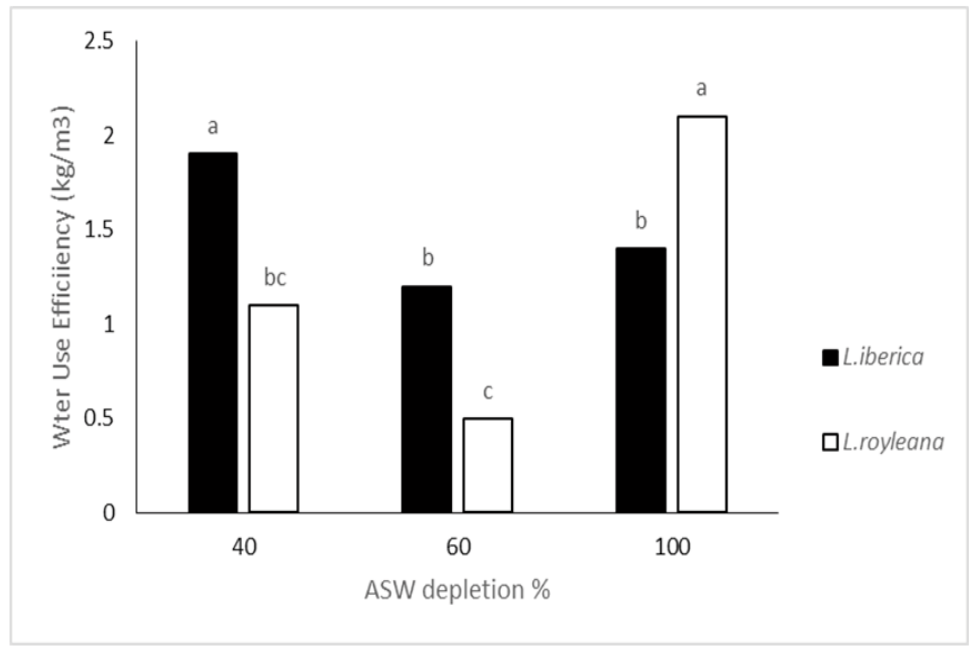

Figure 6: The interaction of drought stress and Lallemantia species on Water Use Efficiency (WUE). Different letters indicate significant difference ( $\mathrm{p}$ 0.05) according to Duncan test. 
(2009) who reported that WUE increased under drought stress conditions. Chaves et al. (2003) stated that most plants tend to show an increase in water use efficiency under conditions of mild or moderate water deficiency. This increase results from the non-linear relationship between stomata conductance and carbon assimilation. Water loss is restricted earlier and more intensely than the inhibition of photosynthesis. High WUE reflects an ability to maintain photosynthetic capacity under conditions of water deficiency and a higher resistance to drought (Bota et al., 2001).

\subsection{THE WATER DEPLETION EFFECTS ON YIELD OF LALLEMANTIA SPECIES}

The effect of irrigation was significant $(p<0.05)$ on yield (Table 3 ). The yield response to drought stress is given in Fig 6 . The yield of $\mathrm{I}_{40}$ was significantly higher than those of $\mathrm{I}_{60}$ and $\mathrm{I}_{100}$, but there was no difference between the yields of $\mathrm{I}_{60}$ and $\mathrm{I}_{100}$ (Table 5). As water depletion increased to $60 \%$ and $100 \%$, yield decreased $39.04 \%$ and $33.71 \%$, respectively, compared with $\mathrm{I}_{40}$ (Table 5). Although $S_{1}$ had more yield than $S_{2}$, the amount was not significant. The interactions between drought stress and species were significant (Table 3 ). The highest yield, $297.22 \mathrm{~kg} \mathrm{ha}^{-1}$, was obtained in $\mathrm{I}_{40}$, L.iberica; the lowest grain yield, $63.40 \mathrm{~kg} \mathrm{ha}^{-1}$, was related to $\mathrm{I}_{60}, L$. royleana (Fig. 7).

Grain yield is the main objective of crop production. Grain yield of Lallemantia was significantly affected by drought stress. Mean comparisons showed that the maximum grain yield $\left(208.37 \mathrm{~kg} \mathrm{ha}^{-1}\right)$ was obtained in $\mathrm{I}_{40}$ and the minimum was obtained when $100 \%$ of AWS was evacuated. Treatments $\left(\mathrm{I}_{60}\right)$ and $\left(\mathrm{I}_{100}\right)$ gave similar results; however, there was no significant difference between these treatments. These results are similar with total dry matter and leaf area index. According to the results, even though grain yield was not significantly different in $\mathrm{S}_{1}$ and $\mathrm{S}_{2}, \mathrm{~S}_{1}$ showed more grain yield compared with $S_{2}$. This might be related to a correlation between grain yield with total dry matter and leaf area index. Weber et al. (1996) reported that both leaf area index and total dry matter were poor predictors of grain yield. Winter and Ohlrogge (1993) suggested that grain yield in each treatment increased when leaf area index and total dry matter increased. In this study, grain yield increased when leaf area index increased.

\subsubsection{Thousand seed mass}

Drought stress had a highly significant $(p<$ 0.01 ) effect on 1000-seed mass (Table 3 ). The results of means comparisons indicated that the water stress treatments significantly decreased 1000-seed mass (Table 5). The results also demonstrated that there was significant difference between Lallemantia species. L. iberica showed the highest 1000-seed mass compared with $L$. royleana. Increasing severity of drought stress reduced 1000-seed mass. In fact drought stress reduced leaf area index, stomatal conductance, photosynthetic pigments, and photosynthesis that affected the transferring grain dry matter and 1000-seed mass.

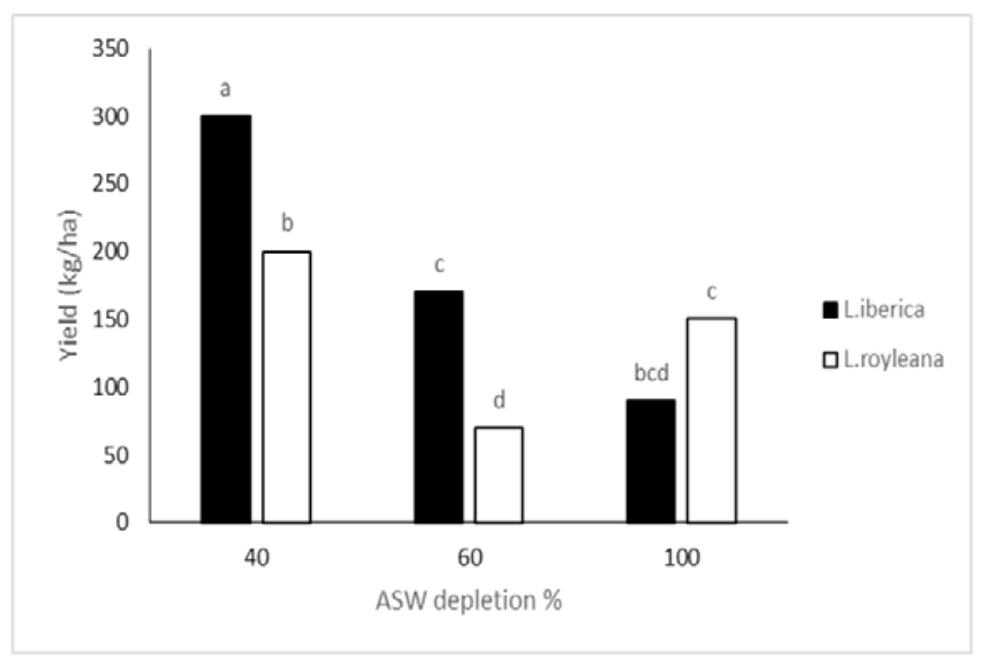

Figure 7: The interaction of drought stress and Lallemantia species on grain yield. Different letters indicate significant difference (p 0.05) according to Duncan test. 


\subsection{THE WATER DEPLETION EFFECTS ON SEED QUALITY OF SPECIES}

\subsubsection{Mucilage}

Data indicated the percentage of seed mucilage was affected by the irrigation treatments (Table 4 ). As drought intensity increased, the percentage of seed mucilage decreased (Table 5). The highest percentage of mucilage was related to $\mathrm{I}_{100}$, and the lowest was reported for $\mathrm{I}_{40}$. As the intensity of available soil water depletion increased to $60 \%$ and $100 \%$, the mucilage percentage increased $13.33 \%$ and $30.3 \%$, respectively. There was a significant difference in the percentage of seed mucilage between Lallemantia species. L. royleana with $7.51 \%$ showed the highest percentage of seed mucilage compared with $L$. iberica. Mucilage yield was significantly affected by irrigation treatments. The highest and the lowest mucilage yields $\left(11.22 \mathrm{~kg} \mathrm{ha}^{-1}\right.$ and $\left(6.75 \mathrm{~kg} \mathrm{ha}^{-1}\right)$ were related to $\mathrm{I}_{40}$ and $\mathrm{I}_{60}$, respectively. Although an increase in the severity of drought stress caused the seed mucilage yield to decline, there was no significant difference between the values of $\mathrm{I}_{40}$ and $\mathrm{I}_{100}$. It seems that increased seed coated mucilage in water deficit conditions occurs because of the genetic and morphological adaptation of plants to protect fertile new embryo in severe drought stress. Our results are in agreement with the findings of Rahimi et al. (2011) and contrary to those of Mousavi-Nik (2012). Data shown in Table (5) clearly indicates there were significant differences between drought stress treatments in seed mucilage yield. The decreasing trend of seed mucilage yield as the depletion of available soil water increases may be attributed to the fact that plants in $\mathrm{I}_{60}$ and $\mathrm{I}_{100}$ had fewer seeds/plant (grain yield) than those of $\mathrm{I}_{40}$. In fact, the reduction of grain mucilage yield may be due to the accumulation of salt minerals around the plant roots in drought stress conditions, which impairs the absorption and transport of nutrients to the shoots and ultimately reduces the synthetics of active substance in plants.

\subsubsection{Protein}

Results showed the percentage of seed protein was affected by different irrigation regimes (Table 4). Increasing the intensity of available soil water depletion resulted in decreased seed protein percentage. The highest and the lowest protein contents were obtained in $\mathrm{I}_{40}$ and $\mathrm{I}_{60}$, respectively (Table 5). Increasing the intensity of available soil water depletion up to $60 \%$ resulted in a significantly decreased protein content (3.80\%). Increasing the severity of available soil water depletion to $100 \%$ resulted in a decreased seed protein content (3.01\%), but the decrease was not significant (Table 5). The interaction effects of drought stress and Lallematia species were significant on protein content. Increasing the severity of drought stress resulted in a significant decrease in the protein content of $L$. iberica, however the decrease was not significant in $L$. royleana. Protein yield was affected by the irrigation regimes (Table 4). The effect of interaction between drought stress and Lallemantia species was significant (Fig 8). The highest protein yield was obtained in $\mathrm{I}_{100}, L$. royleana, and the lowest was reported in $\mathrm{I}_{60}, L$. royleana. Increasing the intensity of available soil water depletion up to $60 \%$ resulted in a decrease in protein yield in both

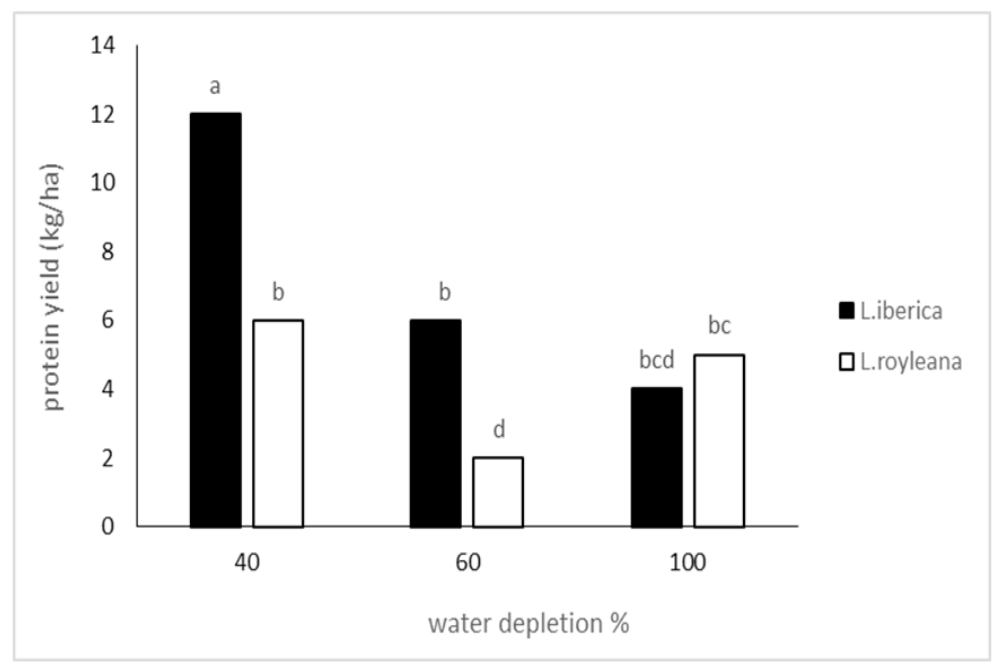

Figure 8: The interaction of drought stress and Lallemantia species on protein yield. Different letters indicate significant difference (p 0.05) according to Duncan test. 
species, but as water depletion increased to more than $60 \%$, protein yield increased. Drought stress is one of the most important factors that influence and decrease seed protein content (Daneshian et al., 2002). According to the results of our study, increasing the severity of drought stress resulted in decreased seed protein percentage, which is in agreement with the results of Johnson et al. (2002). One of the factors reducing seed protein content in plants exposed to drought stress may be severe drop of the photosynthesis productions and subsequent reductions in precursor protein production and may be attributed to a decrease in protein synthesis (Mohamadkhani \& Haydari, 2008). In fact drought stress reduces protein content by increasing the activity of protein degrading enzymes and decreasing photosynthesis. The highest protein yield of $\mathrm{I}_{100}$ was related to the increased adaption of plants to drought conditions from the beginning of growth compared to those reported for $\mathrm{I}_{60}$ and $\mathrm{I}_{40}$. Our results were consistent with those of Musallam et al. (2004) and contrary to those obtained by Alghamdi (2003). The allocation of photosynthetic substrates was expected to be high among plants under $\mathrm{I}_{40}$ compared with $\mathrm{I}_{60}$. The seeds of these plants were also expected to have less protein, but a higher yield.

\section{CONCLUSION}

The present study was designed to determine the effect of soil moisture content on ecophophysiological responses of Lallemantia species. This study has shown that L. royleana has tolerance to water shortage in soil. Despite drought reduced leaf area index, stomatal conductance, and photosynthetic pigments, which ultimately reduces grain yield, water use efficiency significantly increased with the increment in severity of drought stress especially in L.royleana. The evidence from this study suggests that Lallemantia is an efficient plant in low input systems of water supply. An implication of this is the possibility for producer to use Lallemantia as an important medicinal and industrial plant to grow in low input systems in which water scarcity is the most limiting growth factor. This research extended our knowledge about Lallemantia species responses specially water use efficiency under water shortage condition in soil. This is the first study reporting water use efficiency of two species of Lallemantia. However these findings are limited by the use of one seed lot of each species. It is recommended that further research be undertaken with 3 or more seed lots.

\section{REFERENCES}

Acuqaah, G. (2002). Principle of Crop Production, Theory, Techniques and Technology. Prentice-Hall of India, Co. Pvt. Itd.
Akbarinia, M., Zarafshan, M., Sattarian, A., Sustani, F., Ghanbari, E., \& Chaplagh Paridari, I. (2012(. Morphological variations in stomata, epidermal cells and trichome of sweet chestnut (Castanea sativa Mill.) in Caspian ecosystem. Taxonomy and Biosystematics, 3(7), 23-32.

Alghamdi, S.S. (2003). Effect of various water regimes onproductivity of some faba varieties in central region of Saudi Arabia. Agricultural ResearchCenter, King Saud University, 124, 5-22.

Anonymous, (1998). Retrieved from www.lemnaTec.com.

Anonymous, (2003). Retrieved from http://www.inaro.de/ Deutsch/KULTURPF/Drachenkopf/Anbaute.html

Anonymous, (2012). Retrieved from http:// dehkade frood. Blogfa. Com.

Anyia, A.O., \& Herzog, H. (2004). Water Use Efficiency, Leaf gas Exchange of Cowpeas under Mid-season Drought. European Journal Agronomoy, 20, 327-339. https://doi. org/10.1016/S1161-0301(03)00038-8

Arnon, D.L. (1994). Copper enzymes in isolatied chloroplasts, Polyphenol oxidase in Beta vulgaris. Plant Physiology, 24, 1-15. https://doi.org/10.1104/pp.24.1.1

Bota, J., Flexas, J., \& Medrano, H. (2001) .Genetic variability of photosynthesis and water use in Balearicgrapevine cultivars. Annual Applied.Biology, 138, 353-361. https://doi. org/10.1111/j.1744-7348.2001.tb00120.x

Boyer, J.S. (1970). Leaf enlargement and metabolic rates in corn, soybean, and sunflower at various leaf water potentials. Plant Physiology, 46, 233-235. https://doi.org/10.1104/ pp.46.2.233

Chaves, M.M. (1991). Effects of water deficits on carbon assimilation. Journal of Experimental Botany, 42, 1-16. 353-361 https://doi.org/10.1093/jxb/42.1.1

Chen, R.D., \& Tabaeizadeh, Z. (1992). Alteration of gene expression in tomato plants (Lycopersicon esculentum) by drought and salt stress. Genome, 35, 385-391. https://doi. org/10.1139/g92-058

Cornic, G. (2000). Drought stress inhibits photosynthesis by decreasing stomatal aperture - not by affecting ATP synthesis. Trends Plant Science, 5, 187-188. https://doi.org/10.1016/ S1360-1385(00)01625-3

Daneshian, J., \& Jonubi, P. (2002). Effect of drought stress and calcium in soybean characteristics. Agronomy Science, 1, 95-108.

Escalona, J.M., Flexas, J., \& Medrano, H. (1999). Stomatal and non-stomata limitations of photosynthesis underwater stress in field-grown grapevines. Australian journal of plant physiology, 26, 421-433. https://doi.org/10.1071/PP99019

Farooq, M., Wahid, A., Kobayashin., Fujita, D., \& Basra, S.M.A. (2009). Plant drought stress: effects, mechanisms and management. Agronomy for Sustainable Development, 29, 153188. https://doi.org/10.1051/agro:2008021

Flexas, J., Bota, J., Loreto, F., Cornic, G., \& Sharkey, T.D. (2004) Diffusive and metabolic limitations to photosynthesis under drought and salinity in C3 plants. Plant Biology, 6, 1-11. https://doi.org/10.1055/s-2004-820867

Garrity, D.P., Watts, D.G., Sullivan, C.Y., \& Gilley, J.R. (1982). Moisture deficits and grain-sorghum performance evapotranspiration yield relationships. Agronomy Journal, 74, 
815-820. https://doi.org/10.2134/agronj1982.00021962007 $400050011 \mathrm{x}$

Gebeyehu S, (2006). PhD Thesis, Justus-Liebig-Universitat (Giessen, Germany).

Ghanbari, A.K., Shakiba, M.R., Toorchi, M., \& Ghoukan, R. (2013). Morpho-physiological responses of common bean leaf to water deficit stress. European Journal of Experimental Biology, 3(1), 487-492. Retrieved from www.pelagiaresearchlibrary.com

Gupta, N. K., \& Gupta, S. (2005). Pant Physiology. Oxford and IBH Publishing. Herbinger K.,Tausz, M., Wonisch, A., Soja, G, Sorger A., \& Grill, D. (2002). Complex interactive effects of drought and ozone stress on the antioxidant defense systems of two wheat cultivars. Plant Physiology and Biochemistry, 40, 691-696. https://doi.org/10.1016/S09819428(02)01410-9

Harley, A.M., Atkins, S., Budantsev A.L., Cantino, P.D., Conn, B.J., Grayer, R., Harley, M.M., DE Kok. R., Krestovskaja, T., Morals, R., Paton, AJ., Ryding, O., \& Upson, F. (2004). Lamiaceae. In: Kadereit JW (ed.), The Families and Genera of Vascular Plants, 7, 167-275. Springer, New York. https:// doi.org/10.1007/978-3-642-18617-2_11

Herralde, F.de., Savé, R., Biel C., Batlle I., \& Vargas, F. J. (2001). Differences in drought tolerance in two almond cultivars: 'lauranne' and masbovera'. Cahiers - Options Méditerranéennes, 56, 149-154.

Hetherington, A.M., \& Woodward, F.I. (2003). The role of stomata in sensing and driving environmental changes. $\mathrm{Na}$ ture, 424, 901-908. https://doi.org/10.1038/nature01843

Hopkins, R., Schmitt, J., \& Stinchcombe, J. R. (2008). A latitudinal cline and response to vernalization in leaf angle and morphology in Arabidopsis thaliana (Brassicaceae). New Phytologist, 179, 155-164. https://doi.org/10.1111/j.14698137.2008.02447.x

Iturbe Ormaetxe, I., Escuredo, P.R., Arrese-Igor, C., \& Becana, M. (1998). Oxidative damage in pea plants exposed to water deficit or paraquat. Plant Physiology, 116, 173-181. https://doi.org/10.1104/pp.116.1.173

Jaleel, C.A., Manivannan, P., Lakshamanan, G.M., Gomathinayagamm, M., \& Panneerselvam, R. (2008). Alterations in morphological parameters and photosynthetic pigment responses of Catharanthus roseus under soil water deficits. Colloids and Surfaces B: Biointerfaces, 61, 298-303. https:// doi.org/10.1016/j.colsurfb.2007.09.008

Kawamitsu, Y., Driscoll, T., \& Boyer, J. S. (2000). Photosynthesis during desiccation in an Intertidal Alga and a Land Plant. Plant Cell Physiology, 41(3), 344-353. https://doi. org/10.1093/pcp/41.3.344

Klamkowski, K., \& Tender, W. (2008). Response to drought stress of three strawberry cultivars grown under greenhouse conditions. Journal of Fruit and Ornamental Plant Research, 16, 179-188.

Kpyoarissis, A., Petropoulou, Y., \& Manetas, Y. (1995). Summer survival of leaves in a soft-leaved shrub (Phlomis fruticosaL., Labiatae) under Mediterranean field conditions: avoidance of photoinhibitory damage through decreased

chlorophyll contents. Journal of Experimental Botany, 46, 1825-1831. https://doi.org/10.1093/jxb/46.12.1825
Kumar, A., Omae, H., Egawa, Y., Kashiwaba., K., \& Shono, M. (2005). Influence of water and high temperature stresses on leaf water status of (Phaseolus vulgaris L.). Japanese Journal of Tropical Agriculture, 49, 109-118.

Mafakheri, A., Siosemardeh, A., Bahramnejad, B., Struik, P.C. \& Sohrabi, Y. (2010). Effect of drought stress on yield, proline and chlorophyll contents in three chickpea cultivars. Australian Journal of Crop Science, 4(8), 580-585.

Mahmood, S., Hayat, M.Q, Sadiq, A., Ishtiaq, Sh., Malik, S., \& Ashraf, M. (2013). Antibacterial activity of Lallemantia royleana (Benth.) indigenous to Pakistan. African Journal of Microbiology Research, 7(31), 4006-4009.

Manivannan, P., Abdul Jaleel, C., Sankar, B., Kishorekumar, A., Somasundaram, R., Lakshmanan, G.M.A., Panneerselvam, R. (2007). Growth, biochemical modifications and proline metabolism in Helianthus annuus L. as induced by droughtstress. Colloids and Surfaces B: Biointerfaces, 59, 141-149. https://doi.org/10.1016/j.colsurfb.2007.05.002

Martin, D.L., Stegman, \& E.C., Freres, E. (1990). Irrigation scheduling principles. In Hoffman, G.L., Howell, T.A., Solomon, K.H. (Eds), Mnanagement offarm Irrigation Systems. American Society of Agricultural Engineers Monograph, 155-372.

Mohammad Khani, N., \& Heidari, R. (2008). Effects of drought stress on soluble proteins in two maize varieties, Turkish Biology, 32, 23-30. https://doi.org/10.2478/v10020-0080029-8

Mousavi Nik, M., (2012). Effect of different levels of sulfur on yield and quality of Plantago Ovate L. under drought stress in Baluchistan region. Agriculture Ecology, 4(2), 170-182.

Mssacci, A., Nabiev, S.M., Pietrosantl, L., Nematov, S.K., Chernikova, T.N., Thor, K., \& Leipner, J. (2008). Response of photosynthetic apparatus of cotton (Gossypium hirsutum) to the onset of drought stress under field conditions studied by gas-exchange analysis and chlorophyll fluorescence imaging. Plant Physiology and Biochemistry, 46, 189-195. https://doi. org/10.1016/j.plaphy.2007.10.006

Musallam, I.W., Al-Karaki, G.N., \& Ereifej, K.I. (2004). Chemical rainfed and irrigation conditions. International Journal of Agriculture and Biology, 6, 359-362.

Nagaz, K., Masmoudi, M.M., \& Mechila, N.B. (2009). Yield and water use-efficiency of pearl millet (Pennisetum glaucum (L.) R. Br.) under deficit irrigation with saline water in arid conditions of Southern Tunisia. Agronomy Journal, 3, 9-17. http://medwelljournals.com/abstract/?doi = rjagr.2009.9.17

Naghibi,F., Mosaddegh,M,. Motamed, M.S., \& Ghorbani, A. (2005). Labiatae family in folk medicine in Iran from ethnobotany to pharmacology. Iranian Journal Pharmaceutical Research, 2, 63-79.

Nyachiro, J.M., Briggs, K.G, Hoddinott, J., \& Johnson-Flanagan, A. M. (2001). Chlorophyll content, chlorophyll fluorescence and water deficit in spring wheat. Cereal Research Communications, 29, 135-142.

Omidi H Shams H Seif Sahandi M Rajabian T. 2018. Balangu (Lallemantia sp.) growth and physiology under field drought conditions affecting plant medicinal content. Plant Physiology and Biochemistry, 130, 641-646. https://doi. org/10.1016/j.plaphy.2018.08.014

Ommen, O.E., Donnelly, A., Vanhoutvin, S., van Oijen, 
M., \& Manderscheid, R. (1999). Chlorophyll content of spring wheat flag leaves grown under elevated $\mathrm{CO} 2$ concentrations and other environmental stresses within the ESPACE-wheat project. European Journal of Agronomy, 10, 197-203. https://doi. org/10.1016/S1161-0301(99)00011-8

Pandey RK, Maranville JW \& M.M. Chetima, (2000). Deficit irrigation and nitrogen effects on maize in a Sahelian environment. II. Shoot growth. Agricultural Water Management ,46, 15-27. https://doi.org/10.1016/S0378-3774(00)00074-3

Parker, W. C., \& Pallardy, S. G. (1985). Genotypic variation in tissue water relations of leaves and roots of black walnut (Juglans nigra) seedlings. Physiologia Plantarum, 64, 105-110. https://doi.org/10.1111/j.1399-3054.1985.tb01219.x

Passioura, J.B., (1983). Roots and drought resistance. Agricultural Water Management ,7, 265-280. https://doi. org/10.1016/B978-0-444-42214-9.50025-9

Rahimi, A., Jahansoz, M.R., Madah Hoseini, S., Sajjadnia, A.R, Roosta, H. R., \& Fateh, E. (2011). Water use and water use efficiency of Isabgol (Plantago ovata) and French psyllium (Plantago psyllium) in different irrigation regimes. Australian Journal of Crop Science, 5(1), 71-77.

Ramírez, D.A., Yactayo, W., Gutiérrez, R., Mares, V., De Mendiburu, F., Posadas, A., Quiroz, R. 2014 Chlorophyll concentration in leaves is an indicator of potato tuber yield in water-shortage conditions. Scientia Horticulturae, 168, 202-209. https://doi.org/10.1016/j.scienta.2014.01.036

Rauf, S., \& Sadaqat, H. A. (2008). Identification of physiological traits and genotypes combined to high achene yield in sunflower (Helianthus annuus L.) under contrasting water regimes. Australian Journal of Crop Science, 1, 23-30.

Rechinqer, K.H. (1982). Lallemantia (Labiatae) in Rechinger Flora Iranica, 150: Akademische Drurck U . Verlagsantalt, Graz - Austria.

Reddy, S.R. (1999). Irrigation water management. In Principles of Agronomy (Reddy S.R. Ed.), Kalyani publishers. New Delhi. 346-520

Rivero, R.M., Kojima, M., Gepstein, A., Sakakibara, H., Mittler, R., \& Gepstein, S. (2007). Delayed senescence induces extreme drought tolerance in a flowering plant. Proceeding of the National Academy of sciences of the United States of America, 104, 19631-19636. https://doi.org/10.1073/pnas.0709453104

Romero-Romero, J. L., Inostroza-Blancheteau, C., Orellana, D., Aquea, F., Reyes-Díaz, M., Gil, P. M., Matte, J. P., Arce-Johnson, P. (2018). Stomata regulation by tissue-specific expression of the Citrus sinensis MYB61 transcription factor improves water-use efficiency in Arabidopsis. Plant physiology and biochemistry, 130, 54-60. https://doi.org/10.1016/j. plaphy.2018.06.034

Rostamza, M., Chaichi, M.R., Jahansooz, M.R., \& Alimadadi, A. (2011). Forage quality, water use and nitrogen utilization efficiencies of pearl millet (Pennisetum americanuim
L.) grows under different soil moisture and nitrogen levels. Agricultural Water Management, 98, 1607- 1614. https://doi. org/10.1016/j.agwat.2011.05.014

Salehi, A., Tasdighi, H., Gholamhoseini, M. 2016. valuation of proline, chlorophyll, soluble sugar content and uptake of nutrients in the German chamomile (Matricaria chamomilla L.) under drought stress and organic fertilizer treatments. Asian Pacific Journal of Tropical Biomedicine, 6(10), 886-891. https:// doi.org/10.1016/j.apjtb.2016.08.009

Saraswathi, S.G., \& Paliwal, K. (2011). Drought induced change in growth, leaf gas exchange and biomass production in Albizia lebbeck and Gassia siamea seedlings. Journal Environmental Biology, 32, 173-178.

Sarr, P.S., Khouma, M., Sene, M \& Guisse, A. (2008). Effect of pearl millet-cowpea cropping systems nitrogen recovery, nitrogen use efficiency and biological fixation using the $15 \mathrm{~N}$ tracer techniq. Soil Science Plant Nutrition, 54, 142-147. https:// doi.org/10.1111/j.1747-0765.2007.00216.x

Savé, R., Biel, C., Domingo, R., Ruiz-Sanchez, M.C., \& Torrecillas, A. (1995). Some physiological and morphological characteristics of citrus plants for drought resistance. Plant Science, 110, 167-172. https://doi.org/10.1016/0168-9452(95)04202-6

Tashiro, T., \& Wardlaw, I.F. (1990). The effect of high temperature at different stages of ripening on grain set, grain weight and grain dimensions in the semi-dwarf wheat 'Banks'. Annual Botany, 65, 51-61. https://doi.org/10.1093/oxfordjournals.aob.a087908

Tennante, D. )1975). A test of modified intersect method of estimating root length. Journal of Ecology, 11, 995-1001. https://doi.org/10.2307/2258617

Usher, G. )1974). A Dictionary of Plants Used by Man. Constable and Co. Ltd., London, UK., pp: 619.

Weber, C.R., Shibles, R.M., \& Byth, D.E. (1996). Effect of plant population and row spacing on soybean development and production. Agronomy Journal, 58, 99-102. https:/doi. org/10.2134/agronj1966.00021962005800010034x

Wentworth, M., Murchie, E.H., Gray, J.E., Villegas, D., Pastenes, C., Pinto, M., \& Horton, P. (2006). Differential adaptation of two varieties of common bean to abiotic stress. II. Acclimation of photosynthesis. Journal of Experimental Botany, 57, 699- 709. https://doi.org/10.1093/jxb/erj061

Winter, S.R., \& Ohlrogge, A. J. (1993). Leaf angle, leaf area and corn yield. Agronomy Journal, 65, 395-397. https:/doi. org/10.2134/agronj1973.00021962006500030013x

Zargari, A. (1980). Medical Plants, pp. 113. Tehran: Tehran University Publication, Iran.

Zegada-Lizarazu,W., \& Iijima, M. (2005). Deep root water uptake ability and water use efficiency of pearl millet in comparison to other millet species. Plant Production Science, 8, 454-460. https://doi.org/10.1626/pps.8.454 